\title{
B/MYELOID CELL SIGNATURES IN FLAVOBACTERIUM PSYCHROPHILUM-RESISTANT AND -SUSCEPTIBLE GENETIC LINES OF RAINBOW TROUT.
}

\author{
Catherine Moore $^{1}$, Greg Wiens ${ }^{2}$, and Patty Zwollo ${ }^{1 \S}$ \\ ${ }^{1}$ Department of Biology, College of William and Mary, Williamsburg, VA 23185., ${ }^{2}$ National Center for \\ Cool and Cold Water Aquaculture, USDA-ARS, Kearneysville, WV 25430
}

\begin{abstract}
The common aquaculture pathogen Flavobacterium psychrophilum $(F p)$ causes bacterial cold water disease (BCWD) in the rainbow trout (Oncorhyncus mykiss). For this project, we examined whether resistance to $F p$ is associated with differences in $\mathrm{B}$ /myeloid cell signatures in rainbow trout. The National Center for Cool and Cold Water Aquaculture has bred two genetic lines of rainbow trout: a line of $F p$ resistant fish (ARS-Fp-R or R-line fish) and a line of susceptible fish (ARS-Fp-S, or S-line) having similar genetic background. Earlier studies from our labs have shown that 1) R-line fish have larger spleens than S-line fish, 2) R-line fish have a lower abundance of B lineage cells, and 3) R line fish have a higher abundance of $\mathrm{EBF}^{+}$progenitors. Together, this might suggest that $\mathrm{R}$-line fish have a more robust innate immune response compared to $\mathrm{S}$ line fish. To begin testing this hypothesis, we examined whether R-line fish had a higher abundance of myeloid cells than S-line fish, using antibodies against B/myeloid specific markers in a flow cytometric assay. Using myeloid marker Q4E in combination with early B lymphoid marker EBF, no significant differences between the two fish lines was observed (N 10). However, using myeloid markers Pu1 and Q4E, and B-cell marker Pax5, potential differences were detected between between lines: S-line fish had higher percentages of $\mathrm{Pu} 1^{+} / \mathrm{Q}^{4} \mathrm{E}^{+} / \mathrm{Pax} 5^{-}$cells. $\mathrm{We}$ are currently analyzing additional fish and testing additional markers to better characterize myeloid lineage populations. This should shed light on the immunological mechanism by which R-line fish are better able to survive Fp-challenges than S-line fish.
\end{abstract}

\section{KEYWORDS:}

BCWD

Transcription factors

B cell development

Myeloid development

Rainbow trout

${ }^{\S}$ Corresponding author. Tel +17572211969

Email address:pxzwol@wm.edu 